\title{
ANALISIS SISTEM KRS ONLINE TERHADAP KEPUASAN MAHASISWA UNIVERSITAS XYZ MENGGUNAKAN METODE UTAUT
}

\author{
Devi Yurisca Bernanda ${ }^{1)}$, Albert Yohanes ${ }^{2)}$, James Surya Seputro ${ }^{3)}$, Johanes Fernandes Andry ${ }^{4}$ \\ ${ }^{1,2,3}$ Sistem Informasi, Universitas Bunda Mulia \\ 1,2,3 Jl. Lodan Raya No.2, Daerah Khusus Ibukota Jakarta 14430 Indonesia \\ Email : 'dbernanda@bundamulia.ac.id, 2albertyohanes22@gmail.com,3jamessuryaseputro@yahoo.com, \\ ${ }^{4}$ jf_andry@kreavindo.com
}

\begin{abstract}
Abstrak
Kemajuan teknologi informasi sudah menjadi kebutuhan dan meranah hampir ke setiap aspek kehidupan, salah satunya di perguruan tinggi. Universitas XYZ merupakan salah satu perguruan tinggi yang sudah mengedepankan sistem informasi sebagai fasilitas pelayanan bagi mahasiswa Universitas XYZ dengan menyediakan sistem KRS online. Penerimaan dan penggunaan sistem KRS online oleh mahasiswa Universitas XYZ diukur menggunakan model UTAUT yang dapat menjelaskan minat mahasiswa dalam penggunaan sistem informasi dan perilaku penggunaan berikutnya. Sistem KRS Online yang baik akan meningkatkan kepuasan mahasiswa terhadap sistem layanan akademik yang disediakan Universitas XYZ. Penerapan sistem KRS online tersebut akan dianalisis menggunakan metode UTAUT dengan 4 konstruk utama yaitu performance expectancy, effort expectancy, social influence, dan facilitating conditions dengan tujuan agar dapat meningkatkan kualitas sistem informasi akademik yang dimiliki oleh Universitas XYZ. Dari hasil penelitian dapat diperoleh kesimpulan bahwa performance expectancy, effort expectancy, social influence, dan facilitating conditions berpengaruh positif dan signifikan terhadap kepuasan mahasiswa Universitas XYZ terhadap penerapan sistem KRS Online.
\end{abstract}

Kata Kunci : Sistem, Kepuasan Mahasiswa, KRS Online, UTAUT.

\section{PENDAHULUAN}

Teknologi merupakan hal yang menjadi perhatian dewasa ini dikarenakan kemajuannya yang begitu pesat. Hampir semua organisasi atau institusi memanfaatkan bantuan teknologi informasi dan komunikasi. Kemajuan teknologi informasi juga sudah meranah ke hampir setiap aspek kehidupan manusia. Baik di bidang industri, pemerintahan, kesehatan, ekonomi, pendidikan, dan bidang lainnya [1]. Pada era sekarang ini, pemenuhan kebutuhan hidup manusia pun sudah sangat mudah karena segala sesuatunya dapat dilakukan dengan memanfaatkan kemajuan sistem teknologi informasi [2]. Penerapan teknologi informasi dapat diterapkan di dalam sebuah institusi pendidikan, salah satunya di perguruan tinggi.
Sebagai perguruan tinggi yang baik haruslah memiliki sebuah sistem informasi berupa situs web yang berguna memberikan informasi kepada masyarakat atau mahasiswa tentang instansi tersebut. Tolak ukur dengan adanya informasi-informasi pada situs web ini menjadikan masyarakat mudah melakukan penilaian kualitas dari perguruan tinggi [3].

Universitas XYZ merupakan sebuah perguruan tinggi swasta di Indonesia, yang terletak di Kota Jakarta, tepatnya di Utara Jakarta. Sebagai salah satu perguruan tinggi yang mengedepankan pengembangan teknologi, Universitas XYZ berusaha memberikan berbagai fasilitas pelayanan kepada mahasiswa Universitas XYZ dengan cara menyediakan layanan sistem informasi akademik dengan memanfaatkan teknologi internet.

Sistem informasi yang diteliti dalam penelitian ini adalah sistem KRS Online, yaitu sebuah sistem informasi berbasis online atau web yang dapat membantu proses penyusunan KRS dari setiap mahasiswa. KRS adalah kartu rencana studi mahasiswa yang berisi daftar mata kuliah yang ingin diambil oleh mahasiswa dalam satu semester [4].

Dalam menggunakan sistem KRS Online di Universitas XYZ, mahasiswa hanya perlu memilih paket yang berisi daftar mata kuliah dan kelas yang telah diatur oleh prodinya masing-masing. Sistem KRS Online yang dimiliki oleh Universitas XYZ dapat diukur seberapa besar tingkat penerimaan dan penggunaan sistem yang digunakan oleh mahasiswa Universitas XYZ tersebut.

Salah satu model yang banyak digunakan untuk menganalisis tingkat penerimaan dan penggunaan sistem informasi adalah UTAUT (Unified Theory of Acceptance and Use of Technology). UTAUT dikembangkan oleh Venkatesh dkk pada tahun 2003 berdasarkan delapan teori mengenai penerimaan teknologi [5]. UTAUT memiliki tujuan untuk menjelaskan minat penggunaan dalam menggunakan sebuah sistem informasi dan perilaku penggunaan berikutnya. UTAUT menghipotesiskan ekspektansi kinerja, ekspektansi usaha dan pengaruh sosial mempunyai pengaruh terhadap minat penggunaan sistem informasi. [6].

Sebagai user dari sistem KRS Online, mahasiswa tentu mengharapkan bahwa sistem tersebut dapat berjalan dengan lancar, tidak mengalami kendala yang berarti, dan memudahkan mahasiswa untuk mendapatkan informasi. 
Sistem KRS Online yang berjalan dengan baik tentunya akan meningkatkan kepuasan mahasiswa terhadap layanan sistem KRS Online yang diberikan oleh Universitas XYZ, sehingga dapat meningkatkan kualitas layanan sistem informasi akademik yang dimiliki oleh Universitas XYZ.

Menyadari hal ini, penulis tertarik untuk melakukan analisis penerapan sistem KRS Online terhadap kepuasan mahasiswa Universitas XYZ menggunakan metode UTAUT dengan fokus kepada 4 konstruk utama, yaitu performance expectancy, effort expectancy, social influence, dan facilitating conditions.

\section{TINJAUAN PUSTAKA}

A. Sistem

\section{1) Pengertian Sistem}

Sistem adalah suatu jaringan kerja prosedur-prosedur yang saling berhubungan, berkumpul bersama-sama untuk melakukan suatu kegiatan atau untuk menyelesaikan suatu sasaran tertentu [7].

\section{2) Karakteristik Sistem}

Berikut merupakan karakteristik dari sistem:

a. Batasan (boundary)

Pengembangan dari suatu elemen atau unsur mana yang termasuk di dalam sistem dan unsur mana yang termasuk di luar sistem.

b. Lingkungan (environment)

Segala sesuatu di luar sistem, lingkungan yang menyediakan asumsi, kendala, dan input terhadap suatu sistem.

c. Masukan (input)

Sumber daya (data, bahan baku, peralatan, energi) dari lingkungan yang dikonsumsi dan dimanipulasi oleh suatu sistem.

d. Keluaran (output)

Sumber daya atau produk (informasi, laporan, dokumen, tampilan layer komputer, barang jadi) yang disediakan untuk lingkungan sistem oleh kegiatan dalam suatu sistem.

e. Komponen (component)

Kegiatan-kegiatan atau proses dalam suatu sistem yang mentransformasikan input menjadi bentuk setengah jadi (output). Komponen ini bisa merupakan subsistem dari sebuah sistem.

f. Penghubung (interface)

Tempat di mana komponen atau sistem dan lingkungannya bertemu atau berinteraksi.

g. Penyimpanan (storage)

Area yang dikuasai dan digunakan untuk penyimpanan sementara dan tetap dari informasi, energi, bahan baku, dan sebagainya. Penyimpanan merupakan suatu media penyangga di antara komponen tersebut bekerja dengan berbagai tingkatan yang ada dan memungkinkan komponen yang berbeda dari berbagai data yang sama [8].

\section{B. Sistem Informasi}

1) Pengertian Sistem Informasi:

Menurut kertahadi (1995) dalam buku Hanif Al Fatta, Analisis \& Perancangan Sistem Informasi, mendefenisikan sistem informasi sebagai suatu alat untuk menyajikan sistem informasi dengan cara sedemikian rupa sehingga bermanfaat bagi penerimanya. Tujuannya adalah untuk menyajikan informasi guna pengambilan keputusan pada perencanaan, pemrakarsaan, pengorganisasian.

Menurut Robert A. Laitch dan K. Roscoe Bavis sebagai berikut: "sistem informasi dalam suatu organisasi yang mempertemukan kebutuhan pengolahan transaksi harian, mendukung operasi, bersifat manajerial dan kegiatan strategi dari suatu organisasi dan menyediakan pihak luar tertentu dengan laporan - laporan yang diperlukan [9].

2) Sistem Informasi Akademik: Sistem informasi akademik adalah suatu sistem yang dibuat oleh manusia untuk mengolah data dan informasi yang berkaitan dengan akademik pada suatu organisasi atau instansi pendidikan baik formal maupun informal dari tingkat dasar sampai tingkat perguruan tinggi. Secara singkat sistem informasi akademik adalah aplikasi yang dapat memudahkan dalam pengolahan data dan informasi yang berkaitan dengan hal akademik [10].

\section{KRS (Kartu Rencana Studi)}

KRS (Kartu Rencana Studi) ialah rencana studi mahasiswa yang berisi daftar mata kuliah yang diambil dalam satu semester. Mahasiswa wajib untuk mengisi KRS sesuai dengan jatah sks yang diberi dalam pengambilan mata kuliah [11]. Sedangkan KRS Online merupakan pengisian kartu rencana studi mahasiswa secara online yang dapat dilakukan melalui portal mahasiswa atau aplikasi lainnya.

\section{Model UTAUT}

Model the Unified Theory of Acceptance and Use of Technology (UTAUT) merupakan salah satu model penerimaan teknologi terkini yang dikembangkan oleh Venkatesh, dkk. UTAUT menggabungkan fitur-fitur yang berhasil dari delapan teori penerimaan teknologi terkemuka menjadi satu teori. Kedelapan teori terkemuka yang disatukan di dalam UTAUT adalah theory of reasoned action (TRA), technology acceptance model (TAM), motivational model (MM), theory of planned behavior (TPB), combined TAM and TPB, model of PC utilization (MPTU), innovation diffusion theory (IDT), dan social cognitive theory (SCT). UTAUT terbukti lebih berhasil dibandingkan kedelapan teori yang lain dalam menjelaskan hingga 70 persen varian pengguna (Venkatesh, dkk, 2003).

Setelah mengevaluasi kedelapan model, Venkatesh, dkk. menemukan tujuh konstruk yang tampak menjadi determinan langsung yang signifikan terhadap behavioral intention atau use behavior dalam satu atau lebih di masing-masing model. Konstruk-konstruk tersebut adalah performance expectancy, effort expectancy, social 
influence, facilitating conditions, attitude toward using technology, dan self-efficacy. Setelah melalui pengujian lebih lanjut, ditemukan empat konstruk utama yang memainkan peran penting sebagai determinan langsung dari behavioral intention dan use behavior yaitu, performance expectancy, effort expectancy, social influence, dan facilitating conditions [12].

Tujuan utama penelitian menggunakan UTAUT adalah membantu organisasi untuk memahami bagaimana penggunaan bereaksi terhadap pengenalan teknologi baru (Wang, 2005) [13]. Pada model UTAUT terdapat empat konstruk/variabel yang menjadi faktor penentu langsung yang bersifat signifikan terhadap perilaku penerimaan maupun penggunaan teknologi. Vankatesh (2003) menjabarkan dan mendeskripsikan empat konstruk utama UTAUT yaitu:

1. Ekspektasi kinerja (performance expentancy) didefinisikan sebagai seberapa tinggi seseorang percaya bahwa menggunakan suatu sistem akan membantu dia mendapatkan keuntungan kinerja pekerjaannya.

2. Ekspektasi usaha (effort expectancy), didefinisikan sebagai tingkat kemudahan yang dihubungkan dengan penggunaan suatu sistem. Kalau sistem mudah digunakan maka usaha yang dilakukan tidak akan terlalu tinggi dan sebaliknya jika suatu sistem sulit digunakan maka diperlukan usaha yang tinggi untuk menggunakannya.

3. Pengaruh sosial (social influence), didefinisikan sebagai sejauh mana seorang individual mempersepsikan kepentingan yang dipercaya oleh orang lain yang akan mempengaruhinya menggunakan sistem yang baru.

4. Kondisi fasilitas (facilitating condition) didefinisikan sebagai sejauh mana seseorang percaya bahwa infrastruktur organisasional dan teknikal tersedia untuk mendukung sistem [14].

\section{METODE PENELITIAN}

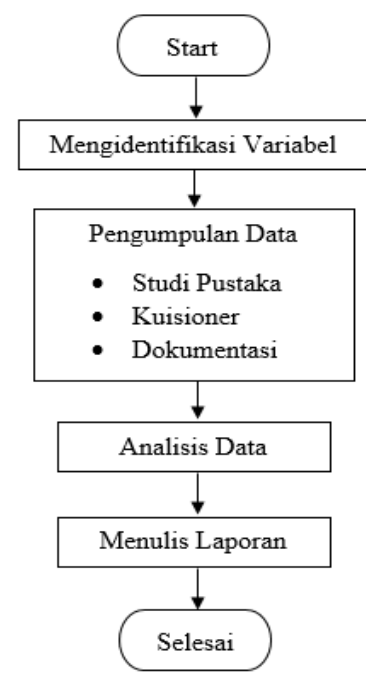

Gambar 1. Flowchart Penelitian
Metode yang digunakan pada penelitian ini adalah metode penelitian kuantitatif. Metode penelitian kuantitatif merupakan metode penelitian yang digunakan untuk meneliti populasi atau sampel tertentu dengan teknik pengambilan sampel pada umumnya dilakukan secara acak. Analisis data penelitian bersifat kuantitatif/statistik dengan tujuan untuk menguji hipotesis yang telah ditetapkan pada penelitian ini [15]. Tahapan penelitian di perlihatkan pada Gambar 1. Flowchart Penelitian.

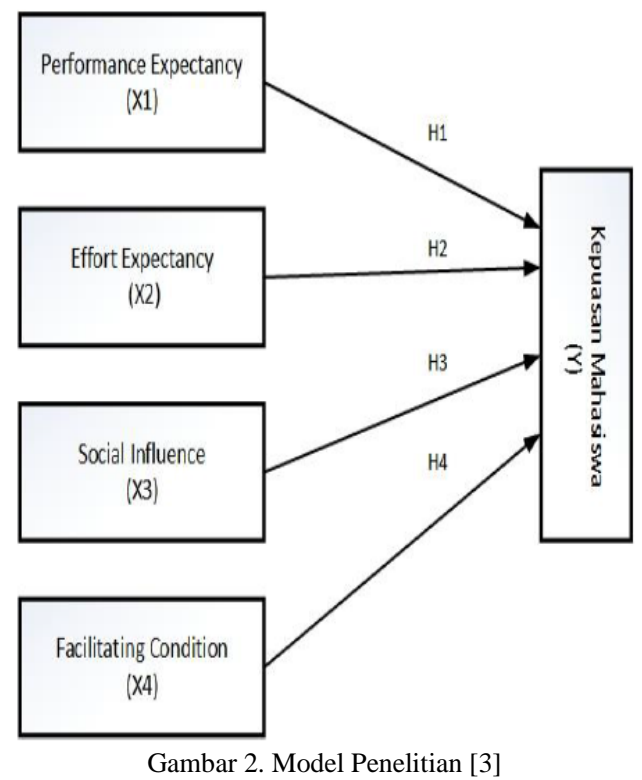

Pada Gambar 2 Model Penelitian menunjukan bahwa masing-masing variabel memiliki hipotesis sebagai berikut:

H1: Ada hubungan antara Performance Expectancy dengan Kepuasan Mahasiswa terhadap Penggunaan KRS Online.

H2: Ada hubungan antara Effort Expextancy dengan Kepuasan Mahasiswa terhadap Penggunaan KRS Online.

H3: Ada hubungan antara Social Influence dengan Kepuasan Mahasiswa terhadap Penggunaan KRS Online. H4: Ada hubungan antara Facilitating Condition dengan Kepuasan Mahasiswa terhadap Penggunaan KRS Online.

Tabel 1 . Indikator Penelitian

\begin{tabular}{|c|c|}
\hline Indikator & Keterangan \\
\hline PEE1 & Persepsi manfaat \\
\hline PEE2 & Meningkatkan efisensi \\
\hline PEE3 & Meningkatkan kenyamanan \\
\hline PEE4 & Bekerja lebih cepat \\
\hline EFE1 & Perampilan pengguna \\
\hline EFE2 & Kemudahan untuk dipelajari \\
\hline EFE3 & Kemudahan interaksi \\
\hline EFE4 & Norma subjektif \\
\hline SOI1 & Faktor social \\
\hline SOI2 & Sumber daya \\
\hline FAC1 & Pengetahuan \\
\hline FAC2 & Dukungan tenaga professional \\
\hline FAC3 & Tingkat kepuasan (saat ini) kualitas layanan \\
\hline KEM1
\end{tabular}




\begin{tabular}{|c|c|}
\hline Indikator & Keterangan \\
\hline KEM2 & $\begin{array}{c}\text { Tingkat kepentingan/harapan kualitas layanan } \\
\text { akademik perguruan tinggi }\end{array}$ \\
\hline
\end{tabular}

Pada penelitian ini digunakan 4 variabel bebas dari model Unified Theory of Acceptance and Use of Technology (UTAUT) yaitu performance expectancy, effort expectancy, social influence, facilitating condition dan variabel terikat user adaption dalam hal ini adalah kepuasan mahasiswa yang dikembangkan oleh peneliti dengan penjelasan indikator dari variabel yang terdapat di dalam Tabel II Skala Likert [3].

Pengumpulan data yang digunakan dalam penelitian ini adalah dengan menyebarkan kuesioner kepada responden yang dililih secara acak dan studi pustaka mengenai metode UTAUT atau penelitian sejenis.

Instrumen penelitian menggunakan skala Likert. Metode pengukuran yang digunakan untuk mengukur sikap, pendapat dan persepsi seseorang atau kelompok tentang fenomena sosial [3]. Skala Likert digunakan sebagai indikator skor daalm pertanyaan kuesioner. Setiap pertanyaan dalam kuesioner memiliki nilai skor 1 sampai 5 atau dapat dilihat pada tabel berikut:

Tabel 2. Skala Likert

\begin{tabular}{|l|l|c|}
\hline No. & Jawaban & Skor Sikap \\
\hline 1 & Sangat tidak setuju & 1 \\
\hline 2 & Tidak setuju & 2 \\
\hline 3 & Ragu-Ragu & 3 \\
\hline 4 & Setuju & 4 \\
\hline 5 & Sangat setuju & 5 \\
\hline
\end{tabular}

Analisis data pada penelitian ini menggunakan analisis statistik. Analisis pertama yang digunakan yaitu uji validitas dengan rumus Product Moment. Validitas dapat diartikan sebagai tingkatan dari keandalan dan kesahihan alat ukur yang digunakan. Dalam uji validitas setiap item pertanyaan kuesioner dibandingkan $r$ hitung dengan $r$ tabel. Jika $r$ hitung $>r$ tabel maka instrument dianggap valid. Jika $r$ hitung $<r$ tabel maka instrument dianggap tidak valid, sehingga instrument tidak dapat digunakan dalam penelitian.

Analisis kedua adalah uji reabilitas. Suatu instrumen dinyatakan bersifat reliabel, bila nilai koefisien reliabilitas minimal 0.60. Berdasarkan penjelasan tersebut, maka dapat diketahui bahwa suatu instrumen dinyatakan bersifat reliabel jika nilai Alpha $\geq 0.60$, sedangkan suatu instrumen dinyatakan tidak reliabel jika nilai Alpha < 0.60 [3].

Analisis ketiga adalah analisis regresi linear sederhana dan uji t-test. Kegunaan analisis regresi linier sederhana adalah untuk mengukur besarnya pengaruh variabel bebas terhadap variabel terikat dan memprediksi variabel terikat dengan menggunakan variabel bebas [3]. Kemudian, uji ttest menunjukkan apakah tiap-tiap variabel bebas (PEE, EFE, SOI, FAC) secara parsial mempunyai pengaruh terhadap variabel bebas tergantung yaitu variabel Y.

\section{IV.HASIL DAN PEMBAHASAN}

Uji validitas dilakukan untuk mengetahui nilai uji validitas dari setiap data kuisioner dengan jumlah responden sebanyak 85 mahasiswa. Pengujian ini menggunakan bantuan tools berupa Software SPSS 22 For Windows. Hasil dari masing-masing uji validitas dapat dilihat pada Tabel III. Uji Validitas Data.

Untuk menunjukkan sebuah butir atau item pertanyaan valid, hasil dari $\mathrm{r}$-hitung $\left(\mathrm{r}_{\mathrm{xy}}\right)$ harus lebih besar dari r-tabel $(\alpha=0.05)$. r-tabel dengan $\mathrm{N}=85$ pada signifikansi 5\% menunjukkan angka 0.213. Dari tabel 4.1 di atas menunjukkan bahwa setiap butir item atau pertanyaan yang terdapat dalam kuesioner valid karena setiap $r$ hitung lebih besar daripada r-tabel.

Tabel 3. Uji Validitas Data

\begin{tabular}{|c|c|c|c|}
\hline $\begin{array}{c}\text { No. } \\
\text { Item }\end{array}$ & r-hitung( $\left.\mathbf{r}_{\mathbf{x y}}\right)$ & $\mathbf{r}$-tabel(a=0.05) & Keterangan \\
\hline 1 & 0.758 & 0.213 & Valid \\
\hline 2 & 0.734 & 0.213 & Valid \\
\hline 3 & 0.761 & 0.213 & Valid \\
\hline 4 & 0.719 & 0.213 & Valid \\
\hline 5 & 0.699 & 0.213 & Valid \\
\hline 6 & 0.775 & 0.213 & Valid \\
\hline 7 & 0.776 & 0.213 & Valid \\
\hline 8 & 0.711 & 0.213 & Valid \\
\hline 9 & 0.644 & 0.213 & Valid \\
\hline 10 & 0.548 & 0.213 & Valid \\
\hline 11 & 0.671 & 0.213 & Valid \\
\hline 12 & 0.623 & 0.213 & Valid \\
\hline 13 & 0.555 & 0.213 & Valid \\
\hline 14 & 0.717 & 0.213 & Valid \\
\hline 15 & 0.653 & 0.213 & Valid \\
\hline
\end{tabular}

\section{B. Uji Reabilitas}

Gambar 3 Hasil Uji Reabilitas dengan bantuan SPSS 22, pada output pertama dalam perhitungan dengan bantuan SPSS adalah "Case Processing Summary", yaitu menjelaskan tentang jumlah data yang valid untuk diproses dan data dikeluarkan serta presentasenya. Dapat diketahui bahwa data atau case yang valid berjumlah 85 dengan presentase $100 \%$.

Case Processing Summary

\begin{tabular}{|c|c|c|c|}
\hline & & $\mathrm{N}$ & $\%$ \\
\hline \multirow[t]{3}{*}{ Cases } & Valid & 85 & 100.0 \\
\hline & Excluded $^{a}$ & 0 & .0 \\
\hline & Total & 85 & 100.0 \\
\hline
\end{tabular}

Reliability Statistics

\begin{tabular}{|c|r|}
\hline $\begin{array}{c}\text { Cronbach's } \\
\text { Alpha }\end{array}$ & N of ltems \\
\hline .914 & 15 \\
\hline
\end{tabular}

Gambar 3. Hasil Uji Reabilitas dengan bantuan SPSS 22

\section{A. Uji Validitas}


Pada output kedua dalam SPSS yaitu "Reliability Statistics", adalah hasil dari analisis reliabilitas dengan teknik Cronbach $\alpha$. Dapat diketahui nilai Cronbach $\alpha$ adalah 0,914. Dari hasil analisis di atas, butir-butir pernyataan dinyatakan diterima dan reliabel karena nilai (0.914) menunjukkan lebih besar dari nilai Cronbach $\alpha=$ 0,6 .

\section{Pengujian Hipotesis}

Pengujian hipotesis menggunakan pengujian analisis regresi sederhana dengan menggunakan statistik t-test dengan bantuan Software SPSS 22 For Windows. Penentuan hasil pengujian hipotesis (penerimaan/penolakan H0) dapat dilakukan dengan cara membandingkan nilai t-hitung dengan nilai t-tabel atau juga dapat dilihat dari nilai signifikansinya.

\section{1) Hipotesis Pertama}

Hipotesis pertama (H1) adalah pengaruh Performance Expectancy (PEE) dengan Kepuasan Mahasiswa (Y) terhadap Penggunaan KRS Online. Adapun analisis regresi sederhana dengan statistik t-test bantuan SPSS dapat dilihat pada Gambar 4. Hasil Analisis Variabel PEE terhadap Y.

\begin{tabular}{|c|c|c|c|c|c|c|}
\hline \multicolumn{7}{|c|}{ Coefficients $^{a}$} \\
\hline \multirow[b]{2}{*}{ Model } & & \multicolumn{2}{|c|}{ Unstandardized Coefficients } & \multirow{2}{*}{$\begin{array}{c}\begin{array}{c}\text { Standardized } \\
\text { Coefficients }\end{array} \\
\text { Beta } \\
\end{array}$} & \multirow[b]{2}{*}{$t$} & \multirow[b]{2}{*}{ Sig. } \\
\hline & & $B$ & Std. Error & & & \\
\hline 1 & (Constant) & .958 & 1.026 & & .934 & .353 \\
\hline & PEE & .392 & .062 & .572 & 6.347 & .000 \\
\hline
\end{tabular}

Gambar 4. Hasil Analisis Variabel PEE terhadap Y

Berdasarkan hasil analisis di atas, diketahui bahwa nilai koefisien regresi variabel Performance Expectancy (PEE) adalah 0.392 dan bernilai positif.

Untuk mengetahui pengaruh tersebut signifikan atau tidak, maka nilai koefisien regresi dari variabel Performance Expectancy (PEE) diuji signifikannya menggunakan uji-t atau t-test dengan mencari nilai t-tabel. Hasil t-tabel yang diperoleh kemudian dicari pada distribusi tabel t. Maka ditemukan nilai t-tabel sebesar 1.667. Berdasarkan gambar 4, didapatkan nilai t-hitung adalah 6.347. Dari perhitungan mencari nilai t-tabel, didapati bahwa nilai t-tabel lebih kecil dibanding dengan nilai t-hitung.

\section{2) Hipotesis Kedua}

Hipotesis kedua (H2) adalah pengaruh Effort Expectancy (EFE) dengan Kepuasan Mahasiswa (Y) terhadap Penggunaan KRS Online. Adapun analisis regresi sederhana dengan statistik t-test bantuan SPSS dapat dilihat pada Gambar 5. Hasil Analisis Variabel EFE terhadap Y.

\begin{tabular}{|c|c|c|c|c|c|c|}
\hline \multicolumn{7}{|c|}{ Coefficients $^{a}$} \\
\hline & & \multicolumn{2}{|c|}{ Unstandardized Coefficients } & $\begin{array}{c}\text { Standardized } \\
\text { Coefficients }\end{array}$ & \multirow[b]{2}{*}{$t$} & \multirow[b]{2}{*}{ Sig. } \\
\hline \multicolumn{2}{|c|}{ Model } & B & Std. Error & Beta & & \\
\hline 1 & (Constant) & 1.730 & .890 & & 1.943 & .055 \\
\hline & EFE & .346 & .054 & .579 & 6.463 & .000 \\
\hline
\end{tabular}

a. Dependent Variable: $Y$

Gambar 5. Hasil Analisis Variabel EFE terhadap Y
Berdasarkan hasil analisis di atas, diketahui bahwa nilai koefisien regresi variabel Effort Expectancy (EFE) adalah 0.346 dan bernilai positif.

Untuk mengetahui pengaruh tersebut signifikan atau tidak, maka nilai koefisien regresi dari variabel Effort Expectancy (EFE) diuji signifikannya menggunakan uji-t atau t-test dengan mencari nilai t-tabel. Hasil t-tabel yang diperoleh kemudian dicari pada distribusi tabel t. Maka ditemukan nilai t-tabel sebesar 1.667. Berdasarkan gambar 5, didapatkan nilai t-hitung adalah 6.463. Dari perhitungan mencari nilai t-tabel, didapati bahwa nilai ttabel lebih kecil dibanding dengan nilai t-hitung.

\section{3) Hipotesis Ketiga}

Hipotesis ketiga (H3) adalah pengaruh Social Influence (SOI) dengan Kepuasan Mahasiswa (Y) terhadap Penggunaan KRS Online. Adapun analisis regresi sederhana dengan statistik t-test bantuan SPSS dapat dilihat pada Gambar 6 Hasil Analisis Variabel SOI terhadap Y.

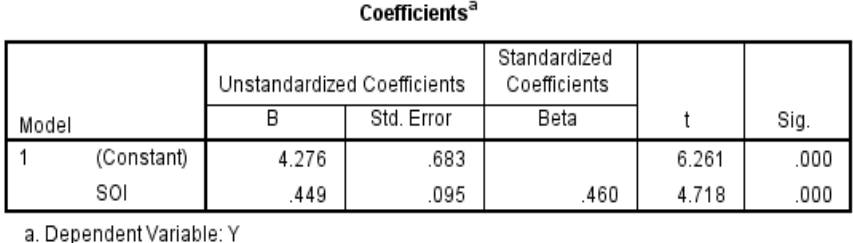

Gambar 6. Hasil Analisis Variabel SOI terhadap Y

Berdasarkan hasil analisis di atas, diketahui bahwa nilai koefisien regresi variabel Social Influence (SOI) adalah 0.449 dan bernilai positif.

Untuk mengetahui pengaruh tersebut signifikan atau tidak, maka nilai koefisien regresi dari variabel Social Influence (SOI) diuji signifikannya menggunakan uji-t atau t-test dengan mencari nilai t-tabel. Hasil t-tabel yang diperoleh kemudian dicari pada distribusi tabel t. Maka ditemukan nilai t-tabel sebesar 1.667. Berdasarkan gambar 6, didapatkan nilai t-hitung adalah 4.718.

\section{4) Hipotesis Keempat}

Hipotesis keempat (H4) adalah pengaruh Facilitating Condition (FEC) dengan Kepuasan Mahasiswa (Y) terhadap Penggunaan KRS Online. Adapun analisis regresi sederhana dengan statistik t-test bantuan SPSS dapat dilihat pada Gambar 7 Hasil Analisis Variabel FEC terhadap Y.

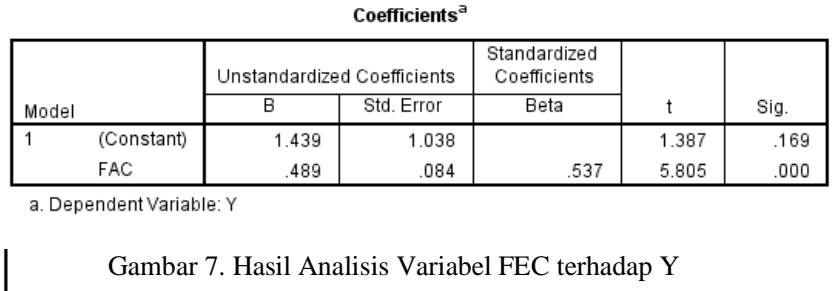

Berdasarkan hasil analisis di atas, diketahui bahwa nilai koefisien regresi variabel Facilitating Condition (FEC) adalah 0.489 dan bernilai positif. 
Untuk mengetahui pengaruh tersebut signifikan atau tidak, maka nilai koefisien regresi dari variabel Facilitating Condition (FEC) diuji signifikannya menggunakan uji-t atau t-test dengan mencari nilai t-tabel. Hasil t-tabel yang diperoleh kemudian dicari pada distribusi tabel t. Maka ditemukan nilai t-tabel sebesar 1.667. Berdasarkan gambar 7, didapatkan nilai t-hitung adalah 5.805.

\section{KESIMPULAN}

Kesimpulan yang dapat diperoleh dari penelitian ini antara lain:

1. Performance Expectancy (Ekspektasi Kinerja) berpengaruh positif dan signifikan terhadap kepuasan mahasiswa Universitas XYZ. Artinya semakin meningkatnya Performance Expectancy (Ekspektasi Kinerja) dalam penerapan sistem KRS Online, maka kepuasan mahasiswa Universitas $\mathrm{XYZ}$ juga meningkat. Kemudian, besarnya pengaruh Performance Expectancy (Ekspektasi Kinerja) terhadap kepuasan mahasiswa adalah sebesar $32.7 \%$ sedangkan $67.3 \%$ kepuasan mahasiswa dipengaruhi oleh variabel lain yang tidak diteliti.

2. Effort Expectancy (Ekspektasi Usaha) berpengaruh positif dan signifikan terhadap kepuasan mahasiswa Universitas XYZ. Artinya semakim meningkatnya Effort Expectancy (Ekspektasi Usaha) dalam penerapan sistem KRS Online, maka kepuasan mahasiswa juga meningkat. Kemudian, besarnya pengaruh Effort Expectancy (Ekspektasi Usaha) terhadap kepuasan mahasiswa adalah sebesar 33.5\% sedangkan $66.5 \%$ kepuasan mahasiswa dipengaruhi oleh variabel lain yang tidak diteliti.

3. Social Influence (Pengaruh Sosial) berpengaruh positif dan signifikan terhadap kepuasan mahasiswa Universitas XYZ. Artinya semakim meningkatnya Social Influence (Pengaruh Sosial) dalam penerapan sistem KRS Online, maka kepuasan mahasiswa juga meningkat. Kemudian, besarnya pengaruh pengaruh Social Influence (Pengaruh Sosial) terhadap kepuasan mahasiswa (Y) adalah sebesar $21.1 \%$ sedangkan $78.9 \%$ kepuasan mahasiswa dipengaruhi oleh variabel lain yang tidak diteliti.

4. Facilitating Condition (Kondisi Fasilitas) berpengaruh positif dan signifikan terhadap kepuasan mahasiswa Universitas XYZ. Artinya semakin meningkatnya Facilitating Condition (Kondisi Fasilitas) dalam penerapan sistem KRS Online, maka kepuasan mahasiswa juga meningkat. Kemudian, besarnya pengaruh Facilitating Condition (Kondisi Fasilitas) terhadap kepuasan mahasiswa adalah sebesar $28.9 \%$ sedangkan $71.1 \%$ kepuasan mahasiswa dipengaruhi oleh variabel lain yang tidak diteliti.

Saran yang dapat diberikan dari hasil penelitian ini antara lain:
1. Meningkatkan kinerja dan pelayanan dari layanan akademik Universitas XYZ dalam hal penerapan sistem KRS Online.

2. Mengawasi dan mengontrol setiap celah terhadap sistem KRS Online dan memperbaiki atau mengganti celah dari sistem tersebut.

3. Menambahkan fasilitas penunjang bagi mahasiswa dalam mengakses atau menggunakan sistem KRS Online.

4. Memudahkan pelayanan atau fitur-fitur sistem KRS Online agar lebih memudahkan mahasiswa dalam mengakses atau mengisi KRS mereka secara online.

\section{DAFTAR PUSTAKA}

[1] R. K. Wiyati, N. L. A. K. Y. Sarja. 2014. "Analisis Awal Penerimaan Aplikasi E-Krs Menggunakan Pendekatan TAM (Technology Acceptance Model)", Konferensi Nasional Sistem dan Informatika 2014; Bali, November 7-8, 2014 KNS\&I14-158.

[2] J. Nasrudin, H. A. Setyadi. 2014. "Intranet Sistem Informasi Akademik STMIK Aub Surakarta Berbasis Mac Address untuk Auto Login", JURNAL ILMIAH GO INFOTECH Volume 20 No. 1, Juni 2014 ISSN: 1693-590x.

[3] L. D. Oktaviana, Z. Rifa'i, K. Utami. 2017. “Analisis Penerapan Sistem KRS Online Terhadap Kepuasan Mahasiswa STMIK Amikom Purwokerto Menggunakan Metode UTAUT", CITISEE 2017 ISBN: 978-602-60280-1-3.

[4] E. Hutabri, A. Alfirini. 2016. "Pengembangan Sistem Informasi Daftar Ulang dan Pengisian KRS Berbasis Web Menggunakan PHP Dan MYSQL", National Conference of Applied Sciences, Engineering, Business and Information Technology. Politeknik Negeri Padang, 15 - 16 Oktober 2016 ISSN: 2541-111x.

[5] B. Mediyanto, I. Mahendra. 2017. "Penerapan Metode UTAUT untuk Memprediksi Behavioral Intentions User dalam Menggunakan Aplikasi Zabbix”, Jurnal Ilmu Pengetahuan Dan Teknologi Komputer Vol. 3. No. 1 AGUSTUS 2017 E-ISSN: 2527-4864.

[6] N. P. K. L. R. K. Dewi, I. K. Yadnyana. 2017. "Faktor-Faktor yang Mempengaruhi Minat dan Perilaku Penggunaan Sistem EFiling di Kota Denpasar dengan Model UTAUT", ISSN: 23028556 E-Jurnal Akuntansi Universitas Udayana Vol.21.3. Desember (2017): 2338-2366.

[7] Hartono, Jugiyanto. 2005. "Analisis dan Desain Sistem Informasi : Pendekatan Terstruktur Teori dan Praktek Aplikasi Bisnis". Yogyakarta: Andi Publisher.

[8] Al Fatta, Hanif. 2007. "Analisis dan Perancangan Sistem Informasi”. Yogyakarta: ANDI.

[9] R. T. Djaelangkara, R. Sengkey, O. A. Lantang. 2015 "Perancangan Sistem Informasi Akademik Sekolah Berbasis Web Studi Kasus Sekolah Menengah Atas Kristen 1 Tomohon”, ejurnal Teknik Elektro dan Komputer (2015); ISSN: 2301-8402.

[10] F. Suryadani, Basori, D. Maryono. 2017. "Pengembangan Sistem Informasi Akademik Berbasis Web Sebagai Sistem Pengolahan Nilai Siswa Di SMK Negeri 1 Kudus", Jurnal Ilmiah Pendidikan Teknik Kejuruan (JIPTEK).

[11] J. Sumarlin. 2015. "Pengembangan Sistem Informasi Akademik Berbasis Web pada Akademi Pariwisata Stipary Yogyakarta". Seminar Nasional Teknologi Informasi dan Komunikasi, ISSN: 2089-9815.

[12] D. Y. Prasetyo. 2017. "Penerapan Metode Utaut (Unified Theory Of Acceptance And Use Of Technology) Dalam Memahami Penerimaan Dan Penggunaan Website Kkn Lppm Unisi”, Jurnal SISTEMASI, Volume 6, Nomor 2, Mei 2017: 26 - 34.

[13] T. Handayani, Sudiana. 2015. "Analisis Penerapan Model Utaut (Unified Theory Of Acceptance And Use Of Technology) Terhadap Perilaku Pengguna Sistem Informasi (Studi Kasus: Sistem Informasi Akademik Pada Sttnas Yogyakarta), Jurnal Angkasa, Volume VII, Nomor 2.

[14] H. Hamrul, B. Soedijono, A. Amborowati. 2013. "Analisis Perbandingan Metode TAM Dan UTAUT Dalam Mengukur Kesuksesan Penerapan Sistem InformasiAkademik (Studi Kasus Penerapan Sistem Informasi STMIK Dipanegara Makassar)". 
Seminar Nasional Informatika 2013 (semnasIF 2013), ISSN: 1979-2328.

[15] N. Hayati. 2015. "Pemilihan Metode Yang Tepat Dalam Penelitian (Metode Kuantitatif Dan Metode Kualitatif)". Jurnal Tarbiyah al-Awlad, Volume IV, Edisi 1, hlm. 345-357. 